International Journal of Management and Sustainability

2021 Vol. 10, No. 4, pp. 92-103.

$\operatorname{ISSN}(e):$ 2306-0662

$\operatorname{ISSN}(p): 2306-9856$

DOI: 10.18488/journal.11.2021.104.92.103

(C) 2021 Conscientia Beam. All Rights Reserved.

check for
updates

\title{
IMPACTS OF MONETARY POLICY ON STABILITY OF COMMERCIAL BANKS - EVIDENCE FROM VIETNAM
}

\author{
Duc Trung \\ Nguyen $^{1+}$ \\ (iD) Thi Nhu Quynh \\ Nguyen ${ }^{2}$
}

\author{
${ }_{1,2}^{1,9}$ Banking University HCMC, Ho Chi Minh City, Vietnam. \\ 'Email: trungnd@buh.edu.vn Tel: +84.983381599 \\ ¿Email: quynhntn@buh.edu.vn Tel: +84.902208422
}

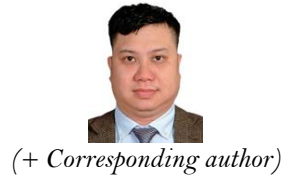

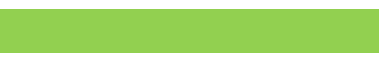

\section{Article History}

Received: 23 August 2021 Revised: 27 September 2021 Accepted: 29 October 2021 Published: 6 December 2021

\section{Keywords}

Monetary policy SGMM

Bayesian approach

Commercial bank

Bank stability

Vietnam.
Before 2009, most central banks conducted their monetary policy with the ultimate goals of promoting price stability, economic growth and full employment. However, the 2009 financial crisis demonstrated that these goals are not enough to maintain a stable financial arena. So, aside from those objectives, the objective of financial stability is also of interest to central banks when implementing monetary policy. In this study, the authors explore the influence of monetary policy on the stability of commercial banks in Vietnam - an emerging economy. The study uses the dataset of the Vietnamese commercial banks from 2008 to 2019, applying SGMM estimations and checking their robustness with a Bayesian approach. The results show that, in recent years, the SBV has effectively implemented monetary policy to ensure banks' stability in Vietnam. In particular, money supply M2 has positively impacted the stability of commercial banks. Also, the results imply that the ratio of loan to total assets, the ratio of cost operating to income operating, as well as CPI, correlate negatively with bank stability. The study did not find any impact of bank size or GDP on bank stability during the research period. Based on these results, the SBV should manage an optimal level of money supply M2 to guarantee efficient economic operations in general and maintain bank stability in particular, and should avoid high inflation.

Contribution/Originality: The study is one of very few studies to investigate the impact of monetary policy on bank stability in a developing economy like Vietnam, using both traditional methods (e.g., GMM) and modern methods (e.g., Bayesian approach) to make the research results more reliable.

\section{INTRODUCTION}

Vietnam, a small-scale emerging economy, is nonetheless taking an increasingly large proportion of the world's economy. Its developing financial system is, however, subordinate to the growth of the banking system. The banking system must therefore operate smoothly and efficiently to ensure sustainable economic development stability in the banking sector is an important prerequisite for GDP growth in the future (Jokipii \& Monnin, 2013). Before 2009, when implementing monetary policy, governments and central banks were often most concerned about achieving the goals of price stability, promoting economic growth, and maintaining full employment. However, with the occurrence of the global financial crisis in 2009, it became clear that these objectives were not sufficient to maintain the staility of the financial system (Bernabe Jr, 2012). Thus, aside from the original goals, the goal of financial stability has come to the forefront of the central banks' monetary policy. Furthermore, the State Bank of Vietnam (SBV) (2021) argues that financial stability is the driving force in improving the effectiveness of 
monetary policy. The reason is that the financial system provides a lot of information that is necessary for the central bank to conduct monetary policy. The financial system is also an important channel through which monetary policy is transmitted to the real economy. Therefore, any instability in the financial system can lead to the ineffective implementation of monetary policy.

Previous studies on the topic of the influence of the monetary framework on bank soundness can be categorized into two groups. The first are those which explore the relationship between monetary framework and bank stability, such as Dell'Ariccia, Laeven, and Marquez (2014); Altunbas., Gambacorta, and Marques-Ibanez (2010b); De Moraes and de Mendonça (2019). Others explore the influence of monetary policy on bank performance (see for example Borio, Gambacorta, \& Hofmann, 2017; Nguyen, Vu, \& Le, 2017). However, most of these studies were conducted in European countries, the US, or other developed countries, rather than emerging economies such as Vietnam. Studies in Vietnam have mainly assessed the impact of monetary policy on economic operations as well as on the banking sector in general, without highlighting bank stability; for example, Ha and Quyen (2018), Quynh (2020), Nguyen, Le, and Tran (2018). Hence, this paper examines the influence of monetary policy on bank stability using the dataset of commercial banks in Vietnam in the period 2008-2019.

This research explores the impact of the monetary framework on bank stabilization and makes several contributions to the existing literature. First, the study contributes an in-depth investigation of the influence of monetary policy on bank stability in a developing economy like Vietnam. Secondly, to explore some problems extracted from the application of a dynamic panel (endogenous, heteroskedasticity, autocorrelations), the model has been processed according to the SGMM method, as suggested by Arellano and Bond (1991). Also, to check the robustness of the model, the analysis is re-checked using the Bayesian approach. When implementing the classical estimation techniques, such as pooled OLS, FEM, REM and GMM, these estimates are dependent only on the data without incorporating prior information, whereas in the Bayesian approach results are not only based on the dataset but also on prior observations. In addition, the Bayesian approach can overcome the limitation encountered by most previous studies that the database cannot be collected for a long time period by using MCMC sequences. Hence, by combining the GMM and Bayesian estimation methods, the reliability of the research results is increased.

The remainder of this paper is structured as follows. The next section presents a review of the previous literature. Section 3 describes the data, methodology and model, and Section 4 provides some empirical results and robustness checks. The final section summarizes the main conclusions and proposes some recommendations.

\section{LITERATURE REVIEW}

According to Ball (2011), monetary policy forms a critical component of economic policy and has strong effects on employment and people's incomes. It is determined by the central bank. Mishkin (2012) defined monetary policy as the process of regulating the money supply of the central bank to carry out certain goals, such as managing the exchange rate and inflation, achieving full employment, and growing the economy. Yeyati and Sturzenegger (2010) stated that monetary policy is the money management process of the monetary authorities, often aimed at achieving the desired interest rate to bring about price stability and economic growth. According to Madura (2014), monetary policy has a strong impact on economic growth and interest rates and therefore affects the value of most assets in the financial market. Particularly in the operation of commercial banks, monetary policy has impacts via three main markets: the currency market, bond market, and mortgage market (Bernanke \& Blinder, 1992). In the currency and bond markets, the effects of monetary policy come through interest rates or issuance and trading bond (or other valuable papers). In the mortgage market, monetary policy influences people's demand for housing, the interest rate on new loans, and the risk premium for mortgages (Madura, 2014).

According to Mishkin (1996), Bruno and Shin (2015) and Neuenkirch and Nöckel (2018), there are five channels in the transmission mechanism of the monetary framework; these are interest rates, lending, asset price, 
exchange rate, and risk-taking. Among these channels, the channels of interest rate, credit, risk-taking, and asset price influence bank stability.

Firstly, bank stability is affected through the interest rate channel. According to Nair and Anand (2020), there is a link between monetary policy and financial stability, and this relationship is often quite complex and mutual. Therefore, the authors compared the interest rate and asset price from the standard Taylor rule in India. The results show that the interest rate well about the Taylor rule motivates price stability. Based on quarterly unbalanced data for 121 commercial banks in Brazil in the period of March 2001 to June 2015, using the SGMM estimator, De Moraes and de Mendonça (2019) found that when the central bank adjusts to increase the interest rate, these banks become more stable and secure. On the other hand, the banks may be exposed to risks and lower lending standards when the interest rate is reduced. They therefore suggest that it is necessary to coordinate monetary and macroprudential policies to maintain bank stability. Similarly, when investigating the data of Spanish banks in the period 2002:02 to 2008:12, Jiménez, Ongena, Peydró, and Saurina (2014) explained the positive relationship between short-term interest rate and bank portfolio risk. The study also discovered that lowcapitalization banks tend to grant more loans to ex-ante risky firms than higher capitalized banks with lower overnight rates. However, regarding the long-term interest rate, they found no such effects. In addition to these studies, Altunbas et al. (2010b) examined the impact of short-term interest. Using quarterly data on the balance sheet of 1,100 banks listed in 16 European countries, the researchers concluded that low short-term interest rates maintained over a long period of time contribute to an increase in bank risk.

Secondly, bank stability is also influenced by the lending (credit) channel, as has been mentioned by several studies. According to Mishkin (1996), when the central bank implements an expansionary monetary policy by reducing the reserve requirement, banks increase their lending. This makes their stability a more significant concern. Indeed, when considering the relationship between loan growth and the riskiness of banks, Foos, Norden, and Weber (2010) used a dataset of more than 16,000 individual banks in 16 major countries (including 13 European countries, the US, Japan, and Canada) in the period 1997-2007. By estimating pooled OLS and GMM models, the researchers suggested that loan growth is the important motivation for the riskiness of banks. Specifically, their results implied that an increase in loans causes banks to increase their loan loss provisions for the next three years. That is the reason why banks decrease relative interest income and the ratio of capital. Furthermore, the authors proved the negative relationship between loan growth and risk-adjusted interest income. Similarly, Salas and Saurina (2002) confirmed that lending growth increases overdue loans and leads to nonperforming loans, based on their use of panel data from commercial and savings banks in Spain between 1985 and 1997. They found that the larger the number of loans a bank has, the greater the bank's risk. Sobarsyah et al. (2020) analyzed the impact of credit growth on the credit risk of 217 Islamic banks from 38 different countries in the period 2010-2019. They demonstrated that higher credit growth increased credit risk as well as bank instability.

Thirdly, the risk-taking channel also adversely affects bank stability. Using quarterly data from 194 American banks between 1998Q1 and 2015Q5, Djatche (2019) suggests that banks' risk behavior is affected by low interest rates created by the previous monetary regime. Examining the data of more than 1000 banks from 29 emerging economies during 2000-2012, Chen, Wu, Jeon, and Wang (2017) showed that monetary policy affects bank risk tolerance via adverse selection. Moreover, the paper found that one of the main causes of bank-adjusting leverage is monetary policy, which thus affects the bank's risk-taking as well as the bank's risk assessment. Also, having found similar results, Angeloni, Faia, and Duca (2015); Dell'Ariccia et al. (2014) agree that a decrease in interest rate is one of the reasons for an increase in bank leverage and risk. This is confirmed by Drechsler, Savov, and Schnabl (2018). They argue that when banks are considered risk-taking investors, a lower interest rate could lead to increased bank leverage, reducing the risk premium and generating high market volatility. Also, the research of Blommestein, Eijffinger, and Qian (2011) suggested that adverse selection can change the expected cash flow of 
customers incompatibly, thereby affecting the process of bank loan appraisal and posing a danger to the financial system.

In Vietnam, using data from all 31 commercial banks from 2008-2019, Thach, Trung, and Quynh (2022) investigated the influence of monetary and macroprudential frameworks on bank soundness. The authors imply that monetary policy instruments (money supply M2 and interbank interest rate) positively affect bank stability. Nguyen et al. (2017) investigated the influence of monetary regulation on commercial banks' profitability in the period 20072014. Their results revealed a positive relationship between banks' profitability and monetary policies. Ha and Quyen (2018) assessed the impact of monetary policy and competition on bank risks in the period 2007-2016, using GMM estimation. Their results showed that monetary regulation instruments in Vietnam have a significant impact on the stability of commercial banks. The research indicated that bank risk-taking increases when expanded monetary regulation is implemented. In general, studies on the impact of a monetary policy framework on bank stability could be classified into two groups. Some have analyzed the impact of such policies on bank stability (such as De Moraes and de Mendonça (2019); Dell'Ariccia et al. (2014); Altunbas et al. (2010b). However, these studies have mainly been conducted in advanced countries (such as the US, European countries). Whereas other studies have considered the role of monetary regulation on bank operations or financial stability in general (for example, Nguyen et al. (2017), Thach et al. (2022)). So, further research into the effects of monetary policy on the financial stability of commercial banks is necessary for some reasons. Firstly, to provide empirical evidence on the role of the monetary framework in the stability of commercial banks in an emerging country like Vietnam in recent years. Secondly, to explore the determinants of stability in the banking sector, so that bank managers can modify their strategies to ensure bank stability. Finally, by understanding the impact of each instrument of monetary policy on bank stability, policymakers will be able to implement appropriate regulations.

\section{MODELS, METHODOLOGY AND DATA}

\subsection{Estimation of Bank Stability}

Bank stability is characterized by complex interactions between sectors in the banking system. This study uses the Z-score as a proxy to represent bank stability. The Z-score indicator was developed by Altman in 1968 and has since then been applied to assess the risk of bankruptcy in many different industries. In the banking sector, the Zscore has been used in studies such as Tran, Hassan, Girerd-Potin, and Louvet (2020); Abuzayed, Al-Fayoumi, and Molyneux (2018); Fernández, González, and Suárez (2016). The Z-score indicator is calculated according to the following formula:

$$
Z-\operatorname{score}_{i t}=\frac{R O A_{i t}+E / A_{i t}}{s(R O A)_{i t}}
$$

Where ROA is the ratio of return on total assets, which is calculated by earnings after taxes divided by total assets; $\mathrm{E} / \mathrm{A}$ is the proportion of shareholder's value divided by total assets; $\sigma(\mathrm{ROA})$ is the standard deviation of ROA. According to Kabir, Worthington, and Gupta (2015), $\sigma(\mathrm{ROA})$ can be calculated based on bookkeeping information for the last three consecutive years. The standard deviation of ROA reflects the income fluctuation according to the bank's ability to accept risks and E/A represents the degree of bank leverage. So, the bank's risk will be low (which means increased bank stability), the higher the Z-score gets and vice versa. Because banks' Zscore shows large deviations, in order to limit the negative impact on results, the study uses $\operatorname{lnZ} Z$-score as an alternative indicator for Z-score.

\subsection{The Instrument of Monetary Policy}

Monetary policy is administered by the central bank as a part of their macroeconomic policy, with the objectives of controlling inflation, economic growth, stability of the nation's currency and unemployment, by 
adjusting several instruments, such as money supply and interest rates (Mishkin, 2012). Given this definition, interest rate and money supply are the two key instruments of monetary regulation (Cecchetti, Schoenholtz, \& Fackler, 2006; Chen et al., 2017; Djatche, 2019; Mishkin, 2012). Regarding the money supply, different sorts of money supply have been used, including Mo, M1, M2, and M3. The usage of the money supply depends on the central bank of each country; for example, in the US, FED usually uses the M1 money supply, whereas Vietnam uses the M2 money supply. In Vietnam, the State Bank of Vietnam (SBV) uses reserve requirement, money supply $\mathrm{M} 2$, and rediscount interest rate as instruments to control the monetary framework, which is consistent with Nguyen et al. (2017). However, in recent years, the SBV has rarely changed rediscount interest rates and reserve requirements. Hence, in this paper, the authors use money supply M2 as the sole measure of monetary regulation.

According to Chen et al. (2017), when central banks conduct an expansionary monetary policy, banking instability increases. So when SBV increases the supply of M2 money in the economy, it could be a condition for high inflation. This causes a decline in the real income and investment of individuals, households as well as businesses. This also affects the activities of commercial banks, when their profitability and stability decrease. For these reasons, we expect money supply M2 to display a negative relationship with bank stability.

\subsection{Bank-Characteristic Variables}

The research model considers a number of bank characteristics that can affect bank stability. The variables that are taken into account are bank size, the proportion of loans to total assets, and cost-efficiency.

The bank size variable (BANKSIZE) is calculated by a logarithm of total assets. Abuzayed et al. (2018) suggest that, compared to small banks, larger ones have a greater ability to diversify income sources, so that larger banks tend to be more stable. Hence, we predicted that bank size would relate positively to bank stability. Regarding cost efficiency, the ratio of cost operating to income operating (CIR) was used as a proxy for this variable. Banks that are managed efficiently are expected to decrease costs and increase their quality of income (Abedifar, Molyneux, \& Tarazi, 2013), leading to enhanced stability. Hence, the CIR ratio is expected to have a negative relationship with bank stability. The proportion of loans to total assets (LOANTA) reflects the main business of bank activity (Abuzayed et al., 2018). Therefore, a higher value of LOANTA may see the bank earning more profit, but they might have to deal with increased credit risk as well as liquidity risk and moral hazard borrowers. Therefore, we expect a negative relationship between LOANTA and bank stability.

\subsection{Macroeconomic Variables}

Aside from bank characteristic variables, the stability of commercial banks is also affected by macroeconomic conditions. Therefore, the research employs two variables, GDP growth and inflation, as proxies for the macroeconomic conditions. In particular, a rise in GDP growth and a decrease in the inflation rate (CIP) will motivate a bank to earn more profit, so this condition is also likely to boost stability. The previous studies of Chen et al. (2017) and Djatche (2019) also made use of these 2 variables.

\subsection{Specification of Model}

Following Altunbas, Gambacorta, and Marques-Ibanez (2010a); Altunbas et al. (2010b); Altunbas, Gambacorta, and Marques-Ibanez (2012); Chen et al. (2017); De Moraes and de Mendonça (2019); Djatche (2019), the authors estimate the following model:

Bank stability $=\mathrm{f}($ monetary policy instrument, bank-specific, controls $)$.

More specifically:

$$
\text { Stability }_{i, t}=\text { a Stability }_{i, t-1}+\mu M o P_{i, t}+b M C_{t}+g B S C_{i, t}+q_{i}+j_{t}+e_{i, t}
$$


In which $\mathrm{i}=1, \ldots, 31, \mathrm{t}=2008, \ldots, 2019$, where i refers to bank and $\mathrm{t}$ refers to year. In model (1), the bank stability (Stability) of bank $\mathrm{i}$ in year $\mathrm{t}$ is explained by the lag of this variable; MoP is a representative instrument of monetary policy; MC and BSC represent the macroeconomic variables and the bank's characteristic variables that affect bank stability, respectively. Table 1 provides brief definitions of the variables used in the research model.

Table-1. A brief definition of the variables used in the paper.

\begin{tabular}{|c|c|c|c|c|}
\hline Variable & Description & Data source & $\begin{array}{l}\text { Sign of } \\
\text { expectation }\end{array}$ & Previous Studies \\
\hline \multicolumn{5}{|c|}{ Dependent variable } \\
\hline LnZ & LnZscore $=\operatorname{Ln} \frac{R O A_{i t}+E / A_{i t}}{s(R O A)_{i t}}$ & $\begin{array}{lr}\text { Audited } & \text { financial } \\
\text { statements } & \text { of } \\
\text { commercial banks and } \\
\text { authors' } \\
\text { calculation }\end{array}$ & & $\begin{array}{l}\text { Djatche (2019); } \\
\text { Abuzayed et al. } \\
(2018) ; \text { Chen et al. } \\
(2017) \text {; Fernández et } \\
\text { al. (2016); Boyd, De } \\
\text { Nicoló, and Jalal } \\
\text { (2006), }\end{array}$ \\
\hline \multicolumn{5}{|c|}{ Independent variables } \\
\hline \multicolumn{5}{|c|}{ The variables representing monetary policy } \\
\hline $\ln \mathrm{M} 2$ & $\begin{array}{l}\text { Money supply } \mathrm{M} 2 \text { is natural } \\
\text { of } \mathrm{M} 2\end{array}$ & $\begin{array}{ll}\text { Asian } & \text { Development } \\
\text { Bank } & \\
\end{array}$ & - & Angeloni et al. (2015) \\
\hline \multicolumn{5}{|c|}{ The control variables } \\
\hline \multicolumn{5}{|c|}{ Bank specific variables } \\
\hline BANKSIZE & Logarite of bank total assets & $\begin{array}{lr}\text { Audited } & \text { financial } \\
\text { statements } & \text { of } \\
\text { commercial banks and } \\
\text { authors' } \\
\text { calculation }\end{array}$ & + & $\begin{array}{l}\text { Altunbas, Binici, and } \\
\text { Gambacorta (2018); } \\
\text { Borio et al. (2017); } \\
\text { Chen et al. (2017); } \\
\text { Boyd et al. (2006) }\end{array}$ \\
\hline LOANTA & $\begin{array}{l}\text { The proportion of loans to } \\
\text { total assets }\end{array}$ & $\begin{array}{lr}\text { Audited } & \text { financial } \\
\text { statements } & \text { of } \\
\text { commercial banks and } \\
\text { authors } \\
\text { calculation }\end{array}$ & - & $\begin{array}{l}\text { Chen et al. (2017), } \\
\text { Borio et al. (2017); } \\
\text { Boyd et al. (2006) }\end{array}$ \\
\hline CIR & $\begin{array}{l}\text { Cost to income operating } \\
\text { ratio is calculated by } \\
\text { proportion of operating cost } \\
\text { to operating income }\end{array}$ & $\begin{array}{lr}\text { Audited } & \text { financial } \\
\text { statements } & \text { of } \\
\text { commercial banks and } \\
\text { authors' } \\
\text { calculation }\end{array}$ & - & $\begin{array}{l}\text { Abuzayed et al. } \\
\text { (2018); Borio et al. } \\
\text { (2017); DeYoung and } \\
\text { Roland (2001); } \\
\text { Abedifar et al. (2013), }\end{array}$ \\
\hline \multicolumn{5}{|c|}{ Macroeconomic variables } \\
\hline GDP & Real GDP growth rate & $\begin{array}{l}\text { International monetary } \\
\text { fund (IMF) }\end{array}$ & + & $\begin{array}{l}\text { Djatche (2019); } \\
\text { Altunbas et al. } \\
(2018) ; \text { Chen et al. } \\
(2017)\end{array}$ \\
\hline CPI & Inflation rate $(\%)$ & $\begin{array}{l}\text { International monetary } \\
\text { fund (IMF) }\end{array}$ & - & $\begin{array}{l}\text { Djatche (2019); Chen } \\
\text { et al. (2017) }\end{array}$ \\
\hline
\end{tabular}

\subsection{Data and Methodology}

To investigate the impact of monetary regulation on bank stability in Vietnam, the authors used the data of 27 commercial banks over the period 2008 to 2019. This period was chosen for several reasons. First, these banks published sufficient data for research during this period. In addition, this is a period when the commercial banks underwent many changes. At the same time, they faced many difficulties and challenges due to the global financial crisis, as well as the restructure of the system. The research data consists of dynamic panel data, which often has several problems, such as endogenous issues, heteroskedasticity and autocorrelations. In order to overcome these issues, the authors employed GMM (Generalise Momentum Method) estimators, as suggested by Blundell and Bond (1998). According to Ha and Quyen (2018), the Z-score may have correlations with some independent variables (for example, bank size and loans). Hence, the research model could lead to endogenous issues or heteroskedasticity. Although 2SLS can be used for endogenous processing, the challenge of implementing this 
method is in correctly identifying the instrument variables. To avoid this difficulty, Arellano and Bond (1991) suggest the GMM approach of using the lag of dependent variables as the instrument variables. There are two forms of GMM estimation: system-GMM (S-GMM) and difference-GMM (D-GMM). Both D-GMM and S-GMM are general estimates designed for panels with small $\mathrm{T}$ and large $\mathrm{N}$. The difference between these two methods is that while D-GMM uses differentials to eliminate endogenously, S-GMM uses instrument variables and exogenous variables to solve the issue. Hence, S-GMM has many assumptions but offers better results than D-GMM. S-GMM has an clear increase in efficiency compared to D-GMM. In addition, to check the sign of the coefficient of the variables, the authors also processed several other estimators, including fixed effects (FEM) and random effects (REM).

To ensure the accuracy of the research data, the research database was collected from reliable sources. In particular, bank-level data was derived from annual reports and audited financial statements. Macro-data, including money supply $\mathrm{M} 2$, was extracted from $\mathrm{ADB}$, and the GDP and CPI were taken from the IMF database. Table 2 shows the descriptive statistics for the variables. Table 2 shows that the average lnZ-score of the 27 commercial banks in Vietnam during 2008-2019 was 3.629. Regarding the monetary policy instrument, the mean lnM2 was 15.376. Also, the averages of BANKSIZE, CIR, and LOANTA were 18.292, 0.522 and 0.549, respectively. The mean real GDP growth and inflation rate for the period 2008 to 2019 were $6.2 \%$ and $7.3 \%$ per year, respectively.

Table-2. Some key descriptive statistics of the variables.

\begin{tabular}{c|c|c|c|c|c}
\hline Variable & Obs & Mean & St. dev & Minimum & Maximum \\
\hline $\operatorname{lnZscore}$ & 311 & 3.629 & 1.041 & 1.405 & 8.962 \\
\hline $\operatorname{lnM} 2$ & 311 & 15.367 & 0.564 & 14.299 & 16.174 \\
\hline BANKSIZE & 311 & 18.292 & 1.201 & 14.894 & 21.122 \\
\hline CIR & 311 & 0.522 & 0.138 & 0.225 & 0.927 \\
\hline LOANTA & 311 & 0.549 & 0.128 & 0.194 & 0.852 \\
\hline GDP & 311 & 0.062 & 0.006 & 0.052 & 0.071 \\
\hline CPI & 311 & 0.073 & 0.064 & 0.006 & 0.231 \\
\hline
\end{tabular}

The correlation between the variables in the model is shown in the correlation matrix in Table 3. Correlation coefficients measure the degree of linear relationship between two independent variables, i.e., the degree of dependency of one variable on another. The table shows that almost all of the variables in the model have low correlations, so these variables satisfy the requirements for the research model.

Table-3. Correlation matrix

\begin{tabular}{c|c|c|c|c|c|c|c}
\hline Variable & $\operatorname{lnZ}$-score & $\operatorname{lnM} 2$ & BANKSIZE & CIR & LOANTA & GDP & CPI \\
\hline $\ln Z$-score & 1.000 & & & & & & \\
\hline $\operatorname{lnM} 2$ & 0.164 & 1.000 & & & & & \\
\hline BANKSIZE & 0.136 & 0.456 & 1.000 & & & & \\
\hline CIR & 0.021 & 0.234 & -0.182 & 1.000 & & & \\
\hline LOANTA & 0.035 & 0.321 & 0.184 & -0.046 & 1.000 & & \\
\hline GDP & 0.192 & 0.712 & 0.330 & -0.015 & 0.283 & 1.000 & \\
\hline CPI & -0.112 & -0.768 & -0.345 & -0.203 & -0.258 & -0.418 & 1.000 \\
\hline
\end{tabular}

\section{EMPIRICAL RESULTS}

The estimation results for the research model are presented in Table 4. The coefficients on lnM2 are positive in all regressions, and the $\operatorname{lnM} 2$ variable is statistically significant in the fixed effects model and the SGMM estimator. Additionally, the sign of coefficients of most of the variables in the FEM, REM, and SGMM estimators are similar. As shown in Table 4 with the SGMM estimator, the lnZ-score in the last year, and the ln M2 variable have a positive effect on bank stability at a significance of $1 \%$ and 5\%, respectively, with coefficients of 0.663 and 0.697 , respectively. In contrast, the ratio of CIR, LOANTA, and CPI relate negatively to bank stability, with coefficients 
of 1.965 ; 6.049, and -12.958 , respectively, at a significance of 1\%. Although BANKSIZE and GDP affect bank stability, the coefficients are not statistically significant.

Table-4. The influence of monetary policy on stability of commercial banks in Vietnam.

\begin{tabular}{|c|c|c|c|}
\hline Variable & Fixed effects & Random effects & System GMM \\
\hline $\operatorname{lnZ\text {-score}(t-1)}$ & & & $\begin{array}{c}0.663^{* * * *} \\
(0.215)\end{array}$ \\
\hline $\operatorname{lnM} 2$ & $\begin{array}{l}0.524^{*} \\
(0.314)\end{array}$ & $\begin{array}{c}0.145 \\
(0.240)\end{array}$ & $\begin{array}{c}0.697 * * \\
(0.336)\end{array}$ \\
\hline BANKSIZE & $\begin{array}{l}-0.314 \\
(0.202)\end{array}$ & $\begin{array}{l}-0.006 \\
(0.100)\end{array}$ & $\begin{array}{c}0.001 \\
(0.062)\end{array}$ \\
\hline CIR & $\begin{array}{l}-0.446 \\
(0.533)\end{array}$ & $\begin{array}{l}-0.214 \\
(0.504)\end{array}$ & $\begin{array}{c}-2.545^{* * *} \\
(0.778)\end{array}$ \\
\hline LOANTA & $\begin{array}{l}-0.926 \\
(0.647) \\
\end{array}$ & $\begin{array}{l}-0.510 \\
(0.566) \\
\end{array}$ & $\begin{array}{c}-8.291^{* * * *} \\
(2.590)\end{array}$ \\
\hline GDP & $\begin{array}{l}24.235^{*} \\
(13.229)\end{array}$ & $\begin{array}{l}25.440^{*} \\
(13.087)\end{array}$ & $\begin{array}{c}6.225 \\
(18.038) \\
\end{array}$ \\
\hline CPI & $\begin{array}{l}-0.317 \\
(1.335)\end{array}$ & $\begin{array}{l}-0.345 \\
(1.330)\end{array}$ & $\begin{array}{c}-5.559^{* *} \\
(2.230)\end{array}$ \\
\hline Cons & $\begin{array}{c}0.578 \\
(2.691)\end{array}$ & $\begin{array}{c}0.349 \\
(2.668)\end{array}$ & $\begin{array}{l}-3.690 \\
(3.493) \\
\end{array}$ \\
\hline F-test p-value & 0.0027 & 0.008 & \\
\hline $\mathrm{AR}(1) \mathrm{p}$-value & & & 0.000 \\
\hline $\operatorname{AR}(2)$ p-value & & & 0.243 \\
\hline Sargan p-value & & & 0.134 \\
\hline Number of groups & 27 & 27 & 27 \\
\hline Number of instruments & & & 20 \\
\hline Second stage F-test p-value & & & 0.000 \\
\hline
\end{tabular}

\subsection{Robustness Checks}

This section provides the results of the Bayesian approach estimation to review the influence of monetary policy on bank stability. Compared with traditional estimation methods (for example, Pooled OLS, FEM, REM, GMM, which are based only on the research data), the Bayesian approach estimation results are based on both the dataset and prior observations. Thus the Bayesian approach gives more reliable results than traditional estimates. However, to perform the Bayesian analysis, posterior model specification is the first step that needs to be undertaken. Here, the posterior model is defined in which the probability distribution of all prior model parameters depends on the observed data and some prior choices. Two ingredients are required for the posterior distribution: a likelihood and a prior ingredient. Specifically, a likelihood ingredient provides knowledge on the model parameters based on observed data. A prior ingredient contains prior information on the model parameters. According to the Bayes approach, the posterior distribution is produced by combining the prior information and likelihood as follows

Posterior proportion $\mu$ Likelihood function $\times$ Prior knowledge

The MCMC sampling is applied to estimate the posterior distribution. Regarding the panel data, the generalized linear model of Bayesian multilevel is described as follows:

$\mathrm{Y}=\left\{\mathrm{y}_{\mathrm{ij}}\right\}$ in which $\mathrm{i}=1,2, \ldots, \mathrm{k}$; and $\mathrm{j}=1,2, \ldots, \mathrm{n}$. The generalized linear model could be written as follows: $\mathrm{y}_{\mathrm{ij}}$ $=\alpha_{i}+\beta_{\mathrm{i}} \mathrm{X}+\varepsilon_{\mathrm{ij}}$, in which $\mathrm{X}=\left(\mathrm{x}_{\mathrm{ij} 1}, \mathrm{x}_{\mathrm{ij} 2}, \ldots, \mathrm{x}_{\mathrm{ijp}}\right) ; \alpha_{\mathrm{i}}$ is individual-specific intercept and $\beta_{\mathrm{i}}$ is slope, $\varepsilon_{\mathrm{ij}}$ are the errors.

The likelihood distribution can be written as the following formula:

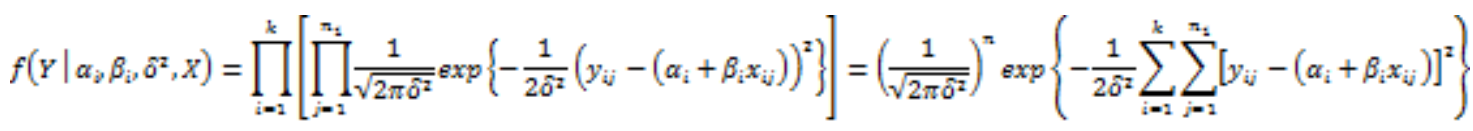

As a matter of fact, prior distribution choice is a complex task in the Bayesian approach. Normally, priors can be inferred from previous, expert opinions or beliefs. However, most previous studies on this topic did not propose a 
particular prior. For this reason, Lemoine (2019) recommends the choice of prior information rely on several estimates. Hence, in this paper, we use the estimated results of the FEM method as prior information.

Table 5 shows the simulation results. This table shows that the sign of the variables in the results of the Bayesian approach is similar to the results of the GMM method (as mentioned above).

Table-5. Simulation results of Bayesian approach.

\begin{tabular}{c|c|c|c|c|c|c}
\hline $\begin{array}{c}\text { Variable } \\
\text { parameters }\end{array}$ & Mean & Std. Dev & $\begin{array}{c}\text { Monte-Carlo } \\
\text { standard error }\end{array}$ & Median & $\begin{array}{c}\text { Probability of } \\
\text { coefficient } \\
\text { mean }>\mathbf{0}\end{array}$ & $\begin{array}{c}\text { Equal-tailed [95\% } \\
\text { Cred. Interval] }\end{array}$ \\
\hline LnM2 & 0.485 & 0.157 & 0.022 & 0.488 & $99.99 \%$ & {$[0.182 ; 0.812]$} \\
\hline BANKSIZE & 0.009 & 0.027 & 0.001 & 0.009 & $61.28 \%$ & {$[-0.045 ; 0.062]$} \\
\hline CIR & -0.912 & 0.401 & 0.023 & -0.910 & $0.78 \%$ & {$[-1.703 ;-0.135]$} \\
\hline LOANTA & -0.755 & 0.481 & 0.013 & -0.753 & $6.00 \%$ & {$[-1.688 ; 0.179]$} \\
\hline GDP & 6.669 & 10.702 & 1.210 & 6.928 & $74.69 \%$ & {$[-14.838 ; 27.331]$} \\
\hline CPI & -0.599 & 1.124 & 0.081 & -0.593 & $29.78 \%$ & {$[-2.801 ; 1.644]$} \\
\hline cons & -3.460 & 1.124 & 0.081 & -0.593 & $4.84 \%$ & {$[-8.056 ; 0.561]$} \\
\hline var & 1.095 & 0.090 & 0.001 & 1.091 & & {$[0.933 ; 1.283]$} \\
\hline
\end{tabular}

\subsection{Discussion}

Based on the empirical results, several things can be noted:

Based on the FEM, SGMM and Bayesian estimators, money supply M2 relates positively to the stability of commercial banks. This result is consistent with Thach et al. (2022), indicating that the economy operates more smoothly and effectively when SBV pumps money into the economy. This is a driving force of financial stability in general and bank stability in particular. Indeed, by increasing money supply (M2), the central bank implements an expansionary monetary framework, which increases individual income, thereby leading to an increase in total demand as well as triggering investment. These result in an increase in economic growth. Although this result differs from that obtained by Quynh (2020), this can be explained by the fact that Quynh (2020) used more limited data (the study was conducted with only 22 commercial banks in Vietnam), so because some of the banks were not included in the sample data in the previous research, it may have caused biased results.

In addition, regarding the control variables, the results in Table 4 show that CIR relates negatively to the lnZscore, which is consistent with the initial expectation and previous studies (for example Abedifar et al., 2013; Abuzayed et al., 2018). Since CIR is a proxy of cost management efficiency, a high-value CIR means that the bank is subject to bad cost management, so the stability of the bank is reduced. This conclusion is consistent with bad management theory. LOANTA also correlates negatively with bank stability. Credit activity is the core business of banks, so commercial banks may have more profit when they increase LOANTA, but it also means that they are subject to certain risks (such as credit risk, liquid risk, ...). Furthermore, BANKSIZE has been shown to positively affect the lnZ-score, although the coefficients are not statistically significant. This means that the size of the commercial banks is not relevant, they can all be stable if they are effectively managed. GDP affects bank stability but the coefficients are not statistically significant, whereas CPI relates negatively to bank stability. Thus, when the economy is operating well, the income of the individuals and households increases, which causes them to raise consumption. This facilitates the efficient operation of businesses, so they can easily pay off their obligations to commercial banks. In general, in a stronger economy, commercial banks are expected to be more stable.

\section{CONCLUSIONS}

In this study, the authors analyzed the influence of monetary regulation on the stability of commercial banks in Vietnam. The paper used the panel data of 27 of a total of 31 commercial banks in Vietnam from 2008 to 2019. The results show that, in recent years, the SBV has effectively implemented monetary policy to maintain financial stability in general and bank stability in particular. Specifically, money supply $\mathrm{M} 2$ has had a positive impact on the 
stability of commercial banks. At the same time, the results indicate that the proportion of loan to total assets (LOANTA), the proportion of cost operating to income operating (CIR) and CPI all correlate negatively with bank stability. However, the study has not discovered any effect of bank size or GDP on bank stability during the research period.

Based upon these results, we put forward a number of policy recommendations: (i) The SBV should continue to use money supply (M2) as an instrument of monetary policy. In order to guarantee efficient and smooth economic operation, as well as curb the inflation rate, SBV should carefully calculate and provide an optimal level of money supply M2. (ii) The results imply that CIR affects bank stability negatively, so bank managers should consider methods of improving their cost management efficiency. (iii) The results suggest that LOANTA is a factor that does not promote the stability of commercial banks, so banks should consider income diversification activities, outside of lending activities. In practice, the diversification of revenue streams as well as the development of new services (digital banking, etc.) is a global trend; hence, Vietnamese commercial banks should take advantage of this opportunity to increase their competitiveness and stability.

Funding: This study received no specific financial support.

Competing Interests: The authors declare that they have no competing interests

Acknowledgement: Both authors contributed equally to the conception and design of the study.

\section{REFERENCES}

Abedifar, P., Molyneux, P., \& Tarazi, A. (2013). Risk in Islamic banking. Review of Finance, 17(6), 2035 -2096.

Abuzayed, B., Al-Fayoumi, N., \& Molyneux, P. (2018). Diversification and bank stability in the GCC. Journal of International Financial Markets, Institutions and Money, 57, 17-43. Available at: https://doi.org/10.1016/j.intfin.2018.04.005.

Altunbas, Y., Gambacorta, L., \& Marques-Ibanez, D. (2010a). Bank risk and monetary policy. Journal of Financial Stability, 6(3), $121-129$

Altunbas, Y., Gambacorta, L., \& Marques-Ibanez, D. (2010b). Does monetary policy affect bank risk-taking? European Central Bank. Retrieved from: http://dx.doi.org/10.2139/ssrn.1654582

Altunbas, Y., Gambacorta, L., \& Marques-Ibanez, D. (2012). Do bank characteristics influence the effect of monetary policy on bank risk? Economics Letters, 117(1), 220-222. Available at: https://doi.org/10.1016/j.econlet.2012.04.106.

Altunbas, Y., Binici, M., \& Gambacorta, L. (2018). Macroprudential policy and bank risk. Journal of International Money and Finance, 81, 203-220. Available at: https://doi.org/10.1016/j.jimonfin.2017.11.012.

Angeloni, I., Faia, E., \& Duca, M. L. (2015). Monetary policy and risk taking. Journal of Economic Dynamics and Control, 52, 285307. Available at: https://doi.org/10.1016/j.jedc.2014.12.001.

Arellano, M., \& Bond, S. (1991). Some tests of specification for panel data: Monte Carlo evidence and an application to employment equations. The Review of Economic Studies, 58(2), 277-297. Available at: https://doi.org/10.2307/2297968.

Ball, L. (2011). Money, banking and financial markets (2nd ed.). USA: Worth Publishers.

Bernabe Jr, E. M. (2012). Framework for Macro-prudential policies for emerging economies in a Globalized environment. Framework for Macro-Prudential Policies for Emerging Economies in a Globalized Environment. Retrieved from: https://econpapers.repec.org/bookchap/searstudy/rp88.htm.

Bernanke, B. S., \& Blinder, A. S. (1992). The federal funds rate and the channels of monetary transmission. The American Economic Review, 82(4), 901-921.

Blommestein, H. J., Eijffinger, S. C., \& Qian, Z. (2011). Monetary policy rules, adverse selection and long-run financial risk. European Banking Center Discussion Paper (No. 2011-032). Retrieved from: http://dx.doi.org/10.2139/ssrn.1963778.

Blundell, R., \& Bond, S. (1998). Initial conditions and moment restrictions in dynamic panel data models. Journal of Econometrics, 87(1), 115-143. Available at: https://doi.org/10.1016/s0304-4076(98)00009-8.

Borio, C., Gambacorta, L., \& Hofmann, B. (2017). The influence of monetary policy on bank profitability. International Finance, 20(1), 48-63. Available at: https://doi.org/10.1111/infi.12104. 
Boyd, J. H., De Nicoló, M. G., \& Jalal, A. M. (2006). Bank risk-taking and competition revisited: New theory and new evidence. USA: International Monetary Fund.

Bruno, V., \& Shin, H. S. (2015). Capital flows and the risk-taking channel of monetary policy. Journal of Monetary Economics, 71, 119-132. Available at: https://doi.org/10.1016/j.jmoneco.2014.11.011.

Cecchetti, S. G., Schoenholtz, K. L., \& Fackler, J. (2006). Money, banking, and financial markets (Vol. 4). USA: McGrawHill/Irwin.

Chen, M., Wu, J., Jeon, B. N., \& Wang, R. (2017). Monetary policy and bank risk-taking: Evidence from emerging economies. Emerging Markets Review, 31, 116-140. Available at: https://doi.org/10.1016/j.ememar.2017.04.001.

De Moraes, C. O., \& de Mendonça, H. F. (2019). Bank’s risk measures and monetary policy: Evidence from a large emerging economy. The North American Journal of Economics and Finance, 49, 121-132. Available at: https://doi.org/10.1016/j.najef.2019.04.002.

Dell'Ariccia, G., Laeven, L., \& Marquez, R. (2014). Real interest rates, leverage, and bank risk-taking. Journal of Economic Theory, 149, 65-99. Available at: https://doi.org/10.1016/j.jet.2013.06.002.

DeYoung, R., \& Roland, K. P. (2001). Product mix and earnings volatility at commercial banks: Evidence from a degree of total leverage model. Journal of Financial Intermediation, 1O(1), 54-84. Available at: https://doi.org/10.1006/jfin.2000.0305.

Djatche, M. J. N. (2019). Re-exploring the nexus between monetary policy and banks' risk-taking. Economic Modelling, 82, 294307. Available at: https://doi.org/10.1016/j.econmod.2019.01.016.

Drechsler, I., Savov, A., \& Schnabl, P. (2018). A model of monetary policy and risk premia. The Journal of Finance, 73(1), $317-373$. Available at: https://doi.org/10.1111/jofi.12539.

Fernández, A. I., González, F., \& Suárez, N. (2016). Banking stability, competition, and economic volatility. Journal of Financial Stability, 22, 101-120. Available at: https://doi.org/10.1016/j.jfs.2016.01.005.

Foos, D., Norden, L., \& Weber, M. (2010). Loan growth and riskiness of banks. Journal of Banking \& Finance, 34(12), 2929-2940. Available at: https://doi.org/10.1016/j.jbankfin.2010.06.007.

Ha, N., \& Quyen, P. (2018). Monetary policy, bank competitiveness and bank risk-taking: Empirical evidence from Vietnam. Asian Academy of Management Journal of Accounting and Finance, 14(2), 137-156.

Jiménez, G., Ongena, S., Peydró, J. L., \& Saurina, J. (2014). Hazardous times for monetary policy: What do twenty-three million bank loans say about the effects of monetary policy on credit risk-taking? Econometrica, 82(2), 463-505. Available at: https://doi.org/10.3982/ecta10104.

Jokipii, T., \& Monnin, P. (2013). The impact of banking sector stability on the real economy. Journal of International Money and Finance, 32, 1-16. Available at: https://doi.org/10.1016/j.jimonfin.2012.02.008.

Kabir, M. N., Worthington, A., \& Gupta, R. (2015). Comparative credit risk in Islamic and conventional bank. Pacific-Basin Finance Journal, 34, 327-353. Available at: https://doi.org/10.1016/j.pacfin.2015.06.001.

Lemoine, N. P. (2019). Moving beyond noninformative priors: why and how to choose weakly informative priors in Bayesian analyses. Oikos, 128(7), 912-928. Available at: https://doi.org/10.1111/oik.05985.

Madura, J. (2014). Financial markets and institutions (11 th ed.). USA: Cengage Learning.

Mishkin, F. S. (1996). The channels of monetary transmission: lessons for monetary policy. Retrieved from: https://www.nber.org/system/files/working_papers/w5464/w5464.pdf.

Mishkin, F. S. (2012). The economics of money, banking, and financial markets: Pearson education.

Mishkin, F. S. (2012). The economics of money, banking, and financial markets (10th ed.). UK: Pearson Education.

Nair, A. R., \& Anand, B. (2020). Monetary policy and financial stability: Should central bank lean against the wind? Central Bank Review, 2O(3), 133-142. Available at: https://doi.org/10.1016/j.cbrev.2020.03.006.

Neuenkirch, M., \& Nöckel, M. (2018). The risk-taking channel of monetary policy transmission in the euro area. Journal of Banking $\mathcal{E}^{2}$ Finance, 93, 71-91. Available at: https://doi.org/10.1016/j.jbankfin.2018.06.003. 
Nguyen, T. L., Le, A. H., \& Tran, D. M. (2018). Bank competition and financial stability: Empirical evidence in Vietnam. In: Anh, L., Dong, L., Kreinovich, V. and Thach, N., Eds., Econometrics for Financial Applications, ECONVN 2018, Studies in Computational Intelligence (Vol. 760). Cham: Springer.

Nguyen, T. N., Vu, N. H., \& Le, H. T. (2017). Impacts of monetary policy on commercial banks' profits: The case of Vietnam. Asian Social Science, 13(8), 32-40. Available at: https://doi.org/10.5539/ass.v13n8p32.

Quynh, N. T. N. (2020). The impact of monetary policy and macroprudential policy on bank stability in Vietnam. Asian Journal of Economics and Banking, 171, 5-26.

Salas, V., \& Saurina, J. (2002). Credit risk in two institutional regimes: Spanish commercial and savings banks. Journal of Financial Services Research, 22(3), 203-224.

Sobarsyah, M., Soedarmono, W., Yudhi, W. S. A., Trinugroho, I., Warokka, A., \& Pramono, S. E. (2020). Loan growth, capitalization, and credit risk in Islamic banking. International Economics, 163, 155-162. Available at: https://doi.org/10.1016/j.inteco.2020.02.001.

State Bank of Vietnam (SBV). (2021). Financial stability and the role of financial stability. Retrieved from: https://www.sbv.gov.vn/webcenter/portal/vi/menu/trangchu/hdk/odtc/gtodtc/odtcvtcod?_afrLoop=37862765766 069224\#\%40\%3F_afrLoop\%3D37862765766069224\%26centerWidth\%3D80\%2525\%26leftWidth\%3D20\%2525\%26ri ghtWidth\%3D0\%2525\%26showFooter\%3Dfalse\%26showHeader\%3Dfalse\%26_adf.ctrl-state\%3Dmkx 1y7n8h_115.

Thach, N. N., Trung, N. D., \& Quynh, N. T. N. (2022). Impact of monetary and macroprudential regulation on bank stability: A bayesian mixed-effects analysis. In: Ngoc Thach N., Ha D.T., Trung N.D., Kreinovich V. (Eds.), Prediction and Causality in Econometrics and Related Topics. ECONVN 2021. Studies in Computational Intelligence (Vol. 983). Cham: Springer.

Tran, D. V., Hassan, M. K., Girerd-Potin, I., \& Louvet, P. (2020). Activity strategies, agency problems and bank risk. Journal of Financial Research, 43(3), 575-613. Available at: https://doi.org/10.1111/jfir.12216.

Yeyati, E. L., \& Sturzenegger, F. (2010). Monetary and exchange rate policies. In Handbook of Development Economics (Vol. 5, pp. 4215-4281). Netherlands: Elsevier.

Views and opinions expressed in this article are the views and opinions of the author(s), International Journal of Management and Sustainability shall not be responsible or answerable for any loss, damage or liability, etc. caused in relation to/arising out of the use of the content. 